\title{
Tumor Antigen-specific Antibody
}

National Cancer Institute

\section{Source}

National Cancer Institute. Tumor Antigen-specific Antibody. NCI Thesaurus. Code C124128.

Any antibody that recognizes antigens that are overexpressed by, mutated in, or predominantly expressed by tumors compared with normal tissues. 